\title{
HELPING STUDENTS UNDERSTAND THE TEXT THROUGH SCAFFOLDING
}

\author{
Deni Sapta Nugraha \\ Indonesian Civil Aviation Institutes, Curug - Tangerang \\ Sapta27@gmail.com
}

\begin{abstract}
This study reported the practice of helping adult students to comprehend the texts in Indonesian Civil Aviation Institute majoring at Air traffic controller programme, Curug - Tangerang. The article demonstrated of how teacher helped them to comprehend the text during 100 minutes reading class in three meetings. It was employed as their input session to acquire context, knowledge and specific vocabulary in aviation or what so called as phraseology. Students were asked to construct some questions dealing with the text both literal and inferential comprehension suggested by Barrett (in Eanes 1997). The result showed that students attained three main bonuses; they get used to build questions that impact to their grammatical awareness, they get used to communicate orally, and they are successful to comprehend the text thoroughly by acquiring new knowledge, vocabulary as well as context.
\end{abstract}

Keywords: Reading Comprehension, Text, Scaffolding.

In Indonesian Civil Aviation Institutes (henceforth ICAI) particularly pilot and ATC students, the main focus of English instruction is to enable them skilled and proficient in speaking and listening skills (ICAO descriptor in Emery \& Roberts, 2008). It is due to the fact that they shall be able to communicate authentically and spontaneously for flight. However, reading is considered important since it provides comprehensible input for students in acquiring new language. Furthermore, the language they learned is exposed to English for aviation that inevitable related to English for specific purpose. Therefore, they are supposed to introduce to new knowledge, context and specific vocabulary that might impede them to comprehend the text and communication as well.

For years, when teachers were employing reading class, the instruction given traditionally was to ask students to answer questions after reading text. The teacher explained the text by using direct translation to the first language instead of elaborating in the target language by his or her own words. What teacher did was relatively nurturing the information into the heads of students without considering what the students had already known and what they needed to know. Even tough, the practice has been indeed attempting to develop the students' knowledge.

In this case, the teacher should actually play a role as an additional power to tackle students' ability in improving their comprehension systematically not as a single model in the classroom. They should help students to go forward a new skills, concept, or level of understanding by considering their current ability. Teachers were responsible to initiate each new step of learning, building on what students currently able to do alone. That is what educator and researchers called as scaffolding.

Scaffolding is believed as a strategy used 
by teachers to facilitate the learners' transition from assisted to independent performance (Cooper, 2000:33-34; Gibbons, 2002). This philosophical underpinning of this approach is explained in the writing of Bruner based partly on the works of Piaget but more considerably on the writing of Vygotsky (Pinter, 2006: 12). Scaffolding is used to support systematically between students' independent level and supported operating level. Roehler and Cantlon (in Hogan \& Pressley, 1997) examined five types of scaffolding including offering explanations, inviting student participation, verifying and clarifying students' understanding, inviting students to contribute clues and modeling of desired behaviors. The third is the key point of "self-made" questions in which the students were asked to make some questions based on the text.

The instruction was intended to push students to a new stage of the development process so that the design should reach a developmental level that is one or more above the students' current developmental level. Scrivener (2002) assumes that students will learn more by doing things themselves rather than by being told about them. He further argues that students are more intelligent not simply receptacles for passed-on knowledge. Learning is not simply a one-dimensional intellectual activity but involve the whole person.

The class I teach is an intermediate class with 25 college students for an air traffic controller class batch 12; most of them have intrinsic motivation and ability to learn by themselves. As for the reading materials given, they can deal with and comprehend more than half of them for the first time reading. Therefore, the teaching strategies that I tend to explain too much is no longer appealing to the students. What the students want is something that can stimulate their interest and make them involved in the activities and ultimately make them understand what they didn't know previously. The scaffolding instruction I presented in the class was much more challenging for the students than usual.

The Theoretical basis

Scaffolding as a teaching approach has been globally employed in the field of teaching English as an international language. This approach can be used to teach four English skills; Speaking, Listening, Reading and Writing.

The theoretical basis and foundation of scaffolding is Vygotsky's Zone of Proximal Development. Vygotsky describes it as "the distance between the actual development level as determined by independent problem solving and the level of potential development as determined through problem solving under adult guidance or in collaboration with more capable peers" (Vygotsky, 1978). The essence of this approach is to help students to move towards from one level to the next level without neither having pressure nor achieving the goal too easily. The technique should be able to elevate students' confidence so that they become aware of being able to accomplish their tasks. The scaffolding is provided by the more knowledgeable person. Teachers gradually and systematically withdraw as the students' competence increased. Eventually, students can complete the task or understand the concepts more independently.

Scaffolding requires the teacher to provide students the opportunity to extend their current skills and knowledge. The teacher must engage students' interest, simplify tasks so they are manageable, and motivate students to pursue the instructional goal. In addition, the teacher must look for discrepancies between students' efforts and the solution, control for frustration and risk, and model an idealized version of the act (Hausfather, 1996). This approach was used to encourage students to be more confident and motivated in comprehending the text. They were asked to attack the text by questioning. They made their own questions based on the text.

METHOD

Traditionally, teacher deliver the reading sheet with some questions, then asked students 
to answer the questions based on the text after reading. However, I have seen that readers have to learn to interrogate the text. The purpose is not only "attacking" the text but also practicing the grammatical awareness and English structure in form of questions. As we know that "having to ask questions on a text is a very good way to ensure that you read it carefully" (Nuttal, 2002: 189-190).

Prior to this classroom activity, I had scaffold the students' knowledge or skills about how to devise questions. The technique used is based on Barrett taxonomy. Barrett (in Eanes 1997) suggests three types of questions commonly used in reading; literal comprehension, inferential comprehension and critical comprehension.

However, not all the criteria were elaborated to students, I just explained about two general criteria; literal question and inferential questions excluding critical questions. In the last of the explanation, I gave them some examples in each type of question until the students understand (See Table I). Besides that, I also gave a brief explanation how to construct the questions grammatically correct.

\section{Table I}

\section{Barrett's Taxonomy of Reading Comprehension(Summarized)}

\begin{tabular}{|c|c|c|}
\hline $\begin{array}{l}\text { Level of } \\
\text { Questions } \\
\text { (Criteria) }\end{array}$ & Literal Questions & Inferential Questions \\
\hline Characteristics & $\begin{array}{l}\text { Focus on ideas and } \\
\text { information which are } \\
\text { explicitly stated in the } \\
\text { text } \\
\text { (vocabulary, difficult } \\
\text { words/phraseology, } \\
\text { proper noun, }\end{array}$ & $\begin{array}{l}\text { Demonstrated by the } \\
\text { students when he/ } \\
\text { she uses the ideas } \\
\text { and information } \\
\text { explicitly stated in } \\
\text { the reading selection, } \\
\text { his/her intuition, } \\
\text { and his/her personal } \\
\text { experiences as a } \\
\text { basis for conjectures } \\
\text { and hypotheses. } \\
\text { (background } \\
\text { knowledge, } \\
\text { hypotheses, } \\
\text { summarize) }\end{array}$ \\
\hline
\end{tabular}

\begin{tabular}{|c|c|c|}
\hline Examples & $\begin{array}{l}\text { Find the following } \\
\text { information: date of } \\
\text { flight, endurance, } \\
\text { speed of the aircraft, } \\
\text { latitude, etc. } \\
\text { What happened when } \\
\text { or during...? } \\
\text { Find the sentence that } \\
\text { tells why.... did(or } \\
\text { was)....? } \\
\text { How many aircrafts } \\
\text { was flown by the } \\
\text { captain? } \\
\text { what knowledge was } \\
\text { gained from...? }\end{array}$ & $\begin{array}{l}\text { What is the article } \\
\text { mainly about? } \\
\text { what does paragraph } \\
\text {... Tells us about? } \\
\text { is there something } \\
\text { in this article that } \\
\text { is not actually said } \\
\text { about...? } \\
\text { If........ an accident) } \\
\text { happened before..... } \\
\text { (another incident), } \\
\text { would it make any } \\
\text { difference in the } \\
\text { story? } \\
\text { Did you ever have } \\
\text { an experience like } \\
\text { this? }\end{array}$ \\
\hline
\end{tabular}

The following are the procedure in the classroom; firstly, I explained that students would conduct a reading activity in form of group consisting 3 persons in each group, a leader then is appointed to conduct the discussion with the other groups after completing the tasks. Next, basic question structures were reviewed about 10 minutes. All students then are allowed to read the text thoroughly about 20 minutes. Each group is required to ask a question at least 8 questions dealing with the text in 25 minutes. The questions should observe the criteria mentioned above, for example: questions about the phraseology or difficult words 3 items, background knowledge or, in this case, aviation knowledge 3 items, summarized questions 1 items, and information about proper noun 1 item (Number of questions are made depend on the teacher).Later, I asked students to discuss their result of discussion by addressing questions to their peer group. Their responsibility was to think the possible answer of other peer's questions. In this section, they not only think about the answer but also comment and criticize the questions itself, whether or not the questions are suitable or grammatically correct. It took about 35 minutes. After the discussion session completed, I clarified certain questions which is ungrammatically correct and inappropriate with the content about 10 minutes. The last, the questions paper of each group were collected to be evaluated and given them written feedback at home. 


\section{FINDINGS AND DISCUSSION}

There were three reading selections given to the students meaning that there have also been three meetings conducted in the classroom. The texts are dealing with aviation field taken from Aviation English written by Henry \& Andy 2008. Text I is about Lost entitled Solo flight to Norfolk Island, Text II is about Technology: Is this the end for Voice Communication?, and Text III is about Meteorology: Microburst a battle against nature.

From the three reading passages, students were relatively eager to get involved in the classroom activity. Initially they felt unusual to make questions based on the texts. In their mind, teacher is the most authoritative to verify their reading comprehension. However, after I explained the goal of the activity was to drill their reading comprehension and grammatical awareness in form of questions, they are eventually ready to "kick off" the class.

The activity from meeting one to meeting three remained the same. However, there are uniqueness that is made by the students. I can see that there are some questions that mostly intense on the same part of the passage, especially on those literal difficult points, even though the questions were formed in different ways. It means that language are recursive linguistically that can transform the ideas in different symbol and structure. One most important thing is that student learn to be more aware on their grammatical awareness. The grammatical mistakes can gradually be improved from meeting to meeting. This is succinctly displayed in the following transcript from 4 groups among 10 (see table II):

\section{Table II. Sentences Transcript}

\begin{tabular}{lll}
\hline Questions Text I & Question text II & Question text III \\
\hline End paragraph & 1. In paragraph 2 & 1. In paragraph 2 \\
3, the phrase “a & line 5, the phrase & line 7, the phrase \\
total endurance" & near-real time & downdraught \\
meaning...... & mean.......(add suffix & means.......(diction, \\
(error occurred) & $\mathrm{s}-$ means) & phrase - word)) \\
\hline
\end{tabular}

\begin{tabular}{|c|c|c|}
\hline $\begin{array}{l}\text { What the } \\
\text { meaning " a total } \\
\text { endurance"? } \\
\text { in paragraph } \\
3 \text { (need to be, } \\
\text { preposition) }\end{array}$ & $\begin{array}{l}\text { 2. What is the } \\
\text { appropriate meaning } \\
\text { "near-real time"?...... } \\
\text { (need -of - meaning } \\
\text { of) }\end{array}$ & $\begin{array}{l}\text { 2. What is the } \\
\text { meaning of } \\
\text { "downdraught"?...... } \\
\text { (no error) }\end{array}$ \\
\hline $\begin{array}{l}\text { What is the same } \\
\text { phrase for "a } \\
\text { total endurance"? } \\
\text { (expression, the } \\
\text { other phrase of... } \\
\text { or the equivalent } \\
\text { phrase of .....) }\end{array}$ & $\begin{array}{l}\text { 3. Can you mention } \\
\text { the synonym of the } \\
\text { phrase "near-real } \\
\text { time"? (no error } \\
\text { occurred) }\end{array}$ & $\begin{array}{l}\text { 3. Can you explain } \\
\text { the meaning of } \\
\text { downdraught? (no } \\
\text { error occurred) }\end{array}$ \\
\hline $\begin{array}{l}\text { Change phrase "a } \\
\text { total endurance" } \\
\text { to Indonesia! } \\
\text { (add article the, } \\
\text {-- the phrase, add } \\
\text { prep. -of--) }\end{array}$ & $\begin{array}{l}\text { 4. Translate the } \\
\text { phrase "near-real } \\
\text { time" into Indonesia } \\
\text { language please! } \\
\text { (Indonesia---- } \\
\text { Indonesian) }\end{array}$ & $\begin{array}{l}\text { 4. Translate the } \\
\text { word downdraught } \\
\text { into Indonesian! (no } \\
\text { error) }\end{array}$ \\
\hline
\end{tabular}

If we compared sentences from meeting I to meeting III, it can be assumed that the questions were formed by the same group of students for each sentence which are systematically the same. I did not give back their papers once at the classroom activity was done but they were given back as the three meetings accomplished. It wasintended to avoid students imitating the sentence structure and ideas already made. Thus, it can be assumed that students' grammatical awareness is relatively improved.

In addition, my observation said that students show great excitement and interests when it is their turn to answer their peer's questions. At this stage, it seems that they can do it more quickly than the stage of devising questions, one reason is that they are very familiar with the material, the other is that they are used to answering questions.

Furthermore, students have answered almost all their peer's questions except for some background knowledge. There are also some weaknesses emerged simultaneously, for instance, the amount of literal question and inferential questions were formed unequally. Also, some questions are too difficult to answer, and even cannot be understood at all. It showed that they need to be more exposed in constructing questions. It is important to mediate students' critical thinking.

In this activity, the students further obtained the chance of communication (the dialogues 
between teacher and students, and students to students) to do something using their target language i.e. English. I can find that even those students who have low self-esteem and low-motivation, do something well out of my expectations. It is due to the fact the gap was created and need to be filled and accomplished to maintain communication without pressure and intimidation. In this case, Students felt comfortable and enjoyable working with their peers. With time limitation they try their best to share, negotiate and make decisions.

Lastly, as I observed their comprehension on reading, students were well-performed in answering questions devised by the teacher. They argue that making the most of questions based on the text help them to understand the text thoroughly. The communication that occurs in this setting with more knowledgeable or capable others (teachers, peers, others) helps the students construct an understanding of the concept (Bransford, Brown, \& Cocking,

\section{REFERENCES}

Beale,J. (2002). Is communicative language teaching a thing of the past? Babel, 37 (1), 12-16.

Bransford, J., Brown, A., \& Cocking, R. (2000). How People Learn: Brain, Mind, and Experience \& School. Washington, DC: National Academy Press.

Cooper, J. D. (2000). Literacy: Helping Children Construct Meaning ( $\left.4^{\text {th }} \mathrm{ed}\right)$. Boston: Houghton Mifflin Company

Celce-Murcia,M., Dornyei, Z., \& Thurrell, S. (1995). Communicative competence: A pedagogically motivated model with content specifications. Issues in Applied Linguistics, 6 (2), 5-35

Eanes, R. (1997). Content Area Literacy: Teaching for Today and Tomorrow. NewYork: Delmar Publishers.

Emery, Henry \& Roberts, Andy. (2008). Aviation English. Oxford: MacMillan Education
2000). "Krashen and other second language acquisition theorists typically stress that language learning comes about through using language communicatively, rather than through practicing language skills (Richards \& Rodgers, 2001; Celce-Murcia, Dornyei \& Thurrell, 1995; Beale, 2002).

\section{CONCLUSION}

In conclusion, this classroom activity was relatively successful to scaffold students mainly on reading comprehension, oral communication as well as raising grammatical awareness. The strategy was also successful to elevate students' motivation to get involved in discussion session, they were no longer reluctant to speak because the idea had already in their mind via clues from questions. Their reading comprehension have also improved due to making questions and discussion. Thus, "utilizing" students' mind is a key feature to dig up their critical thinking and creativity that lead them to be independent learners.

Gibbons, P. 2002). Scaffolding Language, Scaffolding Learning. Portsmouth: Heinemann

Hausfather, Samuel J. (1996). Vygotsky and Schooling: Creating a Social Contest for learning. Action in Teacher Education.

Hogan \& Pressley, K. \& Pressley, M. (1997). Scaffolding Students Learning: Instructional Approach and Issue. Canada: Brookline Books

Nuttall, Christine. (2002). Teaching Reading Skills in a Foreign Language. Shanghai: Shanghai Foreign Language Education Press.

Pinter, A. (2006) Teaching Young Language Learner. China: Oxford University Press

Richards, J. C. \& Theodore S. Rodgers 2001. Approaches and Methods in Language Teaching. Beijing: Foreign Language Teaching and Research Press.

Scrivener, Jim (2002). Learning Teaching: A Guidebook 
for English Language Teachers [M]. Shanghai: Shanghai foreign Language Education Press.

Vygotsky, L.S. (1978). Mind and Society: The Development of Higher Mental Processes.
Cambridge, MA: Harvard University Press.

Widdowson, H. G. (1978). Teaching Language as Communication [M]. Shanghai: Shanghai Foreign Language Education Press. 